\title{
Covid-19: Can This Pandemic Trigger Innovation in Social Work Practice in Slovenia and England?
}

\author{
Petra Videmšek ${ }^{1 *}$ and Joanna Fox ${ }^{2}$ \\ ${ }^{1}$ Faculty of Social Work, University of Ljubljana, Ljubljana, Slovenia \\ ${ }^{2}$ Faculty of Health, Education, Medicine and Social Care, Anglia Ruskin University, UK \\ *Corresponding author: Petra Videmšek, Faculty of Social Work, University of Ljubljana, Ljubljana, Slovenia \\ To Cite This Article: Petra Videmšek, Joanna Fox. Covid-19: Can This Pandemic Trigger Innovation in Social Work Practice in Slovenia and \\ England?. Am J Biomed Sci \& Res. 2021 - 14(2). AJBSR.MS.ID.001977. DOI: 10.34297/AJBSR.2021.14.001977.
}

Received: 眥 September 07, 2021; Published: 跙 September 27, 2021

\begin{abstract}
We discuss how social workers manage the delivery of practice in Slovenia and England, in response to the emergence of Covid-19. We considered: the impact of Covid-19 on social work practice in our two countries and changes by social workers to the use of virtual media and the physical space in response to the pandemic. We discuss if the response to this crisis has the potential in Slovenia to facilitate processes of deinstitutionalisation and explore the potential role of social work in England extending in its role in the community following the pandemic.
\end{abstract}

Keywords: Deinstitutionalization, Digitalisation, ICT, Community social work, long term care

\section{Introduction}

In the past year, since the Coronavirus, known as Covid-19, emerged, our lives have changed in dramatic ways because of the government response to the pandemic. Over the last year, the media reports the shocking data of those who are affected, who have died, and moreover how quickly the virus is spreading around the world. Slovenia is a country with a population of only 2 million; yet on 021.08.21 there were 4781 recorded deaths during the period of the pandemic [1]. The UK is a country of approximately 60 million people; on 04.09.21 (Gov.uk 04.09.21) the number of confirmed deaths recorded in the UK, as a result of the pandemic, was 156,119. Thus, the pandemic has impacted the lives of individuals, families, groups, communities, and institutions.

As governments internationally have responded to the pandemic, we have witnessed the lockdown of factories, schools, retail outlets, and health and social care services; the national and international reactions to contain the spread of virus have resulted in citizens being compelled to practise social distancing with other people [2]. This action not only creates a physical distance but also a social distance from our wider families, friends and community. In this current environment of social distancing, people, regardless of whether they use social care services, experience more social isolation and decreased social contact, which impacts on the wellbeing of vulnerable adults and children.

We are both social workers, working as academics in Slovenia and England. The response of both governments in our two countries to Covid-19 has forced us to adapt our working habits and routines; and we have been compelled to adjust to the new circumstances as private and working lives merge whilst the place of family responsibilities and childcare impinge on work roles. In this article we focus on the impact of this pandemic on social work in our respective countries. We consider how this difficult situation, and the national and international reactions to this pandemic, have made social work practice reshape itself in response to the pandemic.

We explore how this situation poses an opportunity for innovation to revise the care and support provided by social workers in both virtual and physical settings. This is a useful approach as Slovenia is a former communist state, which became independent in 1991; and since that time, has made steady but cautious progress toward an open market economy, joining the European Union in 
2004. Care is predominantly providing through total institutions $[3,4]$. Moreover England, as part of the UK, has a neoliberal economy, which impacts on the delivery of its public services, and the whole UK left the European Union at the end of 2019 [5]. We conclude by questioning whether the current economic status of our countries following months of lockdown may limit service improvement by introducing innovation without change [6].

\section{Process of Reflection}

From March 2020 until the middle December 2020, we exchanged our views and shared the situations as they unfolded in each of our countries. We reflected on the responses to Covid-19 experienced in our separate countries and organised the ideas into a comprehensive whole that showed the changes in our local and national environments. We formulated our main research questions to guide the development of the discussion in this article:

a) What impact does Covid-19 have on social work practice in Slovenia and England?

b) How can social work be conducted in the virtual world?

c) Is this pandemic a potential trigger for innovation in the physical space?

\section{Social Work in The Virtual Space}

Although in both Slovenia and England, social work practice is at different stages and delivered in different ways, we find many similarities to our responses during Covid-19. The context of the delivery of care, affects how practice is organised in each country. During Covid-19, we, as members of the public, and even more so as social workers, are under pressure from governmental administrations to practise social distancing from each other to prevent the spread of the virus. Social distancing [2] incorporates changes in behaviour that prevent disease transmission by reducing contact rates between susceptible individuals and infected individuals who may transmit the disease. In Slovenia and England, all social programmers have been delivered differently from previous practice with practitioners working on-line or via the telephone.

On 18 March 2020, the Ministry of Labour, Family, Social Affairs and Equal Opportunities in Slovenia issued new guidelines to social workers and volunteers [40] which restricted contacts in centers of Social Work to solely virtual connections. Supervised contacts between parents and children were restricted and physical contact was not allowed; residential homes and day-care facilities for children and adults with learning disabilities have closed except when no other care is available. Furthermore, access to day centers for homeless people have been limited and replaced by street-based provision of basic subsistence essentials. Exceptions to digital-only contact were only allowed for emergency situations which required the protection of vulnerable adults or children [4].

Due to the restrictions, social workers had to respond to the changing situations and adapt practice to support vulnerable adults and children. Social workers were aware of the needs that lockdown triggered for many people. A report from [48] confirmed that the number of domestic violence cases rose during the period of lockdown and concluded that mandatory isolation maximizes the risk of violence and maltreatment within families occurring and minimizes access to help and support, although, interestingly, the number of all criminal acts declined during this time [4]. Leskošek et al. [8] also reported about food poverty of young people. In Slovenia, pupils have access to a meal and hot lunch provided by the schools, but when the schools closed, no food was available, and many young people experienced food poverty.

Similarly, in the UK, research by Romanou, et al. [9] (3) reported the negative impact of Covid-19 on vulnerable children as lockdown increased the stressors on caregivers and has led to further risk of abuse as children were no longer able to access their normal protective services and networks. Trussell Trust [10] an organization providing food parcels for those in food poverty in the UK, experienced a sharp rise in demand from those in poverty, unable to provide for their basic subsistence needs. Moreover, it reported an $89 \%$ increase in need for emergency food parcels during April 2020 compared to the same month last year, including a $107 \%$ rise in parcels given to children [10].

In England, social workers continue to undertake multiprofessional partnership working, assessing and safe-guarding vulnerable adults and children, but they must conduct risk assessments focusing on their own health and safety before undertaking their work. BASW [11,12] highlights the need to limit face-to-face meetings and to maintain social distancing whilst undertaking necessary legislative safeguarding; and BASW $[11,12]$ underlines the importance of wearing personal protective equipment whilst conducting such face-to-face assessments. Thus, in response to this situation, in order to assist people, who use services, safely, social workers have adapted the way they care for vulnerable adults and children, but also maintain their own personal health and safety, utilising more connections in the virtual spaces rather than through traditional face-to-face contact.

In both countries, social workers have increasingly used technology to undertake remote assessments to fulfil their legislative duties. Virtual contacts enable elders in care homes to see and hear their sons and daughters on telephones and I-pads; and ICT is utilised to undertake risk assessment and safe-guarding meetings with children and families and vulnerable adults. However, although we acknowledge the potential role of ICT in supporting 
communication and its central role in the current context, there are limitations to its effectiveness: facial expression and non-verbal communications are cues to effective interaction with service users in face-to-face meetings (for example, the SOLER model described by Egan, et al. [13] thus, barriers to communication impact on effective relationship-building.

Despite thislimitation, ICT has a unique role to play in connecting with service users at this particular time; this has led to guidelines being developed to support effective communication. Banks et al. [14] (v) note the importance for social workers of 'Creating and maintaining trusting, honest and empathic relationships via phone or internet with due regard to privacy and confidentiality. This reminder is reflected in the UK context, where social workers are instructed to use ICT appropriately and ethically [15] ensuring that there is transparency about how data is stored and recorded [7].

Both authors outline that it is important not only to promote digital inclusion but to ensure equal access for all to enable service users to connect with social workers in the virtual world. Not all people have equal access to the digital tools to communicate; accordingly, many service users with specific learning needs, or from older age groups, or people from lower socio-economic backgrounds may have limited access to appropriate technology and Wi-Fi to enable them to connect in such ways [16]. ICT needs to be accessible for all, irrespective of ability, language, ethnic or cultural background, social-economic status, and age. Thus, to access support, information on its use needs to be prepared in easy read formats (short, pictures, voice) so that people with visual or hearing impairments, or learning needs, can engage with it easily. Despite this, social work in the virtual world, has many benefits such as enabling people with learning needs to review video materials in advance; and, furthermore, online meetings provide more opportunities to 'talk' via chat or oral media. This approach promotes opportunities for service users to communicate in diverse ways and enables those with visual or hearing impairments to become active participants in online meetings [16].

Although the use of the virtual space can solve many dilemmas during the Covid-19 by enabling limited forms of virtual communications, we believe that social work cannot only take place in the virtual space. Interpersonal connections are therefore essential in the personal interaction that take place in the physical space; and even more so, physical contact was especially missing in care given to older people. From our process of duo ethnography, we identified changes taking place in the physical space in our local environments of Slovenia and England, and then reflected on the commonalities and differences in the wider international context. Firstly, we focus on Slovenia and then on changes in England.

\section{The Potential for Change in The Physical Space}

In Slovenia, many changes to practice have been implemented on both micro and macro levels, however, despite deinstitutionalisation being widely progressed in Europe (and in England) since the mid$20^{\text {th }}$ Century, institutions remain the most common form of care in Slovenia for both older people and those with different disabilities $[3,4,17,18]$. Following the dramatic spread of Covid-19 cases, the provision of care through total institutions left many residents susceptible to contracting coronavirus. Most deaths happened in just three older people's care homes; on 24 of May 2020, 86 out of 108 overall deaths were in care homes for older people (Kovač 2020) with a majority of deaths in three residential homes in the cities of Ljutomer, Metlika and Šmarje pri Jelšah [8].

Although institutions are not currently safe for residents because of the threat of Covid-19, Slovenia has very little existing home and community support, because it relies so heavily on institutional-based care, therefore home-based care is similarly unsafe. It needs to be understood that institutions are themselves a place of potential risk for older and disabled people, more because of the levels of reduced support and regulated lives in total institutions rather than because of the danger of transmission of Covid-19.

This catastrophic situation in care homes led to all residential care facilities for children and young people, and older people being temporarily closed, and residents being sent home to their families to prevent the spread of the virus. Residential homes and day-care facilities for children and adults with learning disabilities were closed except for cases where no other care could be provided. [19] commented that Covid-19 is not only a problem for older people, but for the wider systems of service delivery through total institutions in Slovenia because community care support is underdeveloped and inadequate. Both authors support and acclaim this opinion. Many relatives have been unable to care for their family members at home, [20] reported that only a few families (less than ten) have taken relatives out of care homes; this has led to a call to develop community resources to enable more family-based and user-oriented care for older and disabled people, forcing the community to revisit the question of deinstitutionalization.

In Slovenia, experiences with Covid-19 clearly show that the process of deinstitutionalisation has been delayed for too long. Deinstitutionalisation requires both 'bottom-up' and 'topdown' action, both work on the ground and the development of suitable legislation, policies, and funding instruments to implement the changes [21]. Moreover, community services need to be introduced to provide new opportunities to innovate, 
otherwise deinstitutionalisation will not take place effectively. This extraordinary situation in residential care homes may lead to a dramatic improvement in the way care is provided because Slovenia does not have a uniform system of long-term care. We hope that the crisis may allow the Act for Long-Term Care, a transformative legislative program which has been in process for over 18 years, to be finally implemented. This Act focuses on the provision of personal assistants to support care in the community and designs processes that allow finance to be transferred to community-based services to promote independent living; it holds promise for this development.

Although changes in deinstitutionalisation are on the horizon in Slovenia, we can compare the current status to that of the UK, where the provision of social care is provided predominantly through community-based services. This helps us to understand how the impact of Covid-19 may influence Slovene care services. The UK is committed to providing services in the community, however the gradual retrenchment of the state [22] and cuts to public spending $[23,24]$ following the financial crisis of 2008 , have resulted in the reduction of community services such as day centres, meals on wheels, and community transport [25] This episode of recession led to an emphasis on the rationing of resources to only those with the highest need [26] as the government sought to reduce funding to publicly funded services by rolling back the state [22]. This may indicate that even when service delivery is implemented through care in the community, a visionary form of provision [26] that Slovenia seeks to emulate, reductions in funding may lead to challenges in organizing effective, safe, and reliable care.

Moreover, the enactment of wellbeing has been a guiding focus in legislation for the provision of services for children and families [27] and adults in the community [5]; however, many have questioned the liberating promises of the [5] with its focus on wellbeing in the context of a period of austerity (Whittaker 2016) This meant that an increase in wellbeing was not experienced by many service users; and if deinstitutionalisation is introduced in Slovenia, without adequate preparation and care, then the opportunity found in Covid-19 pandemic to innovate services may fail.

Learning further from the UK, shows that although this country has embraced the process of deinstitutionalisation and adopted care in the community since the early 1980s [25], in contrast to Slovenia, many mini-institutions in the UK still continue to deliver total care in residential settings. Questions have been raised about the quality of support delivered in such establishments, as documented by an under-cover reporter in 2012 [28]. The dangerous care provided in a residential home called Winterbourne View was revealed and the physical and emotional abuse of its residents who had learning difficulties was highlighted. Furthermore, although the UK has ostensibly moved to care in the community, such mini-institutions continue to exist and conceal poor levels of care. [17] also suggests a similar situation in Slovenia exists; she notes that even when people were move from the institutions to the group homes, which support people with mental ill health, continue to exist as mini-institutions. Her research shows that in Slovenia, workers, including social workers, continue to work with an institutional mentality.

This situation suggests that England has still some way to go to deliver safe care, and perhaps reveals the long way that Slovenia must traverse to achieve change. We thus consider that we need to be cautious about the hopes raised to change and innovate care provision in the context of Covid-19; we need to be aware of the dramatic adjustments which will be required to instigate service improvement. Despite this, care in the community is a less expensive form of care than institutionalised care [6], which suggests the potential for its implementation; however, both political will and community-led activism will be needed to implement such change. Moreover, with the slow-down in both national and international economic communities, reductions in government finance due to Covid-19 will limit the potential for change and the government's will to focus on national changes to systems of social care. We now move to explore the potential of community-led services and the implications for social work.

\section{Community Space: The Place of Social Work?}

In the wider context of Europe, in response to the pandemic, many local organisations in Slovenia, England and elsewhere have mobilised to offer both practical and emotional support to people who are either self-isolating or shielding themselves because of their vulnerability to Covid-19 [8,29,30]. This community action is organic rather than structural, it is bottom-up rather than top-down [31] and is not initiated by government or national administrations. In the remainder of the article, we suggest that social workers have the potential skills and capabilities to contribute effectively to the development of such community initiatives $[3,31,32]$ as they respond to the pandemic.

Community Social Work (CSW) has its roots in the socioecological model [33], in which intervention is centred on change to the social networks around a person to build their social capital rather than change focused on the individual him/herself, a theory at the center of social work. It requires a change in focus from person-centred care to investment in communities and mutual aid [34]. This process of mutual aid and community building as communities seek to self-organize and support people is a natural place for social workers to occupy.

The emergence of Covid-19 has challenged the narrow role of the social workers in our respective countries as communities mobilize to meet the needs of vulnerable people [30]. Currently, 
actions to develop mutual support and community mobilization in response to Covid-19 are taking place outside of the social work field. Neighbourhoods have mobilised without the top-down leadership or the philanthropic funding which most charities depend on. There is a need for social workers to evaluate their role and assess their potential as a profession to influence change through extending their roles in communities to innovate and to mobilise mutual aid. This highlights the need for effective community development to be community-led in response to Covid-19.

Despite this vision, in a recent book, [5] suggest that the potential for communities in England to mobilize may have been compromised by austerity, thus limiting the opportunities of communities to respond in a Covid-19 era. These ideas can also be extrapolated to the current situation in Slovenia. [5] emphasize that it is important to value and build on strengths of local people in developing community support; but they underline the need to acknowledge that some localities are much poorer than others in their stock of social as well as economic capital. Similarly, they comment that the social capital in communities was harmed by the long-term effects of recession and austerity which damaged the potential of community to regenerate itself to develop support and self-help systems. They suggest (2019: xxii) 'The enduring effects of hard times may have hardened into enduring social scars.' This discussion leads to the need to understand how community has organised itself in both Slovenia and England following the Covid-19 pandemic and whether there is a place for social work to occupy this physical space.

It is important to acknowledge that the social work profession has a history of supporting mutual aid and community development [34]. Social workers' commitment to social justice and support for service user empowerment [32] suggest the potential for their effective involvement in such processes. However, the wider impact of political recession [31] and the limits on the role of social workers, particularly in the UK [34], suggest that social workers will need to carve out a new niche for themselves to ensure their participation in service change and community activism.

\section{Conclusion}

Despite the invaluable work undertaken by social care workers, the media in both Slovenia and England largely reported of the extreme conditions in hospitals, reiterating the importance of the equipment needed for treatment; and it focused on the role of health care staff as they worked to save the lives of those affected by Covid-19. For a long time, social care workers received less recognition, and their work was perceived by many as invisible. In Slovenia, Danica Hrovatič, president of Association of Social Workers, Slovenia 2020 published a letter critical of governmental measures highlighting the invisibility of social workers and social care services in the media.
In the article we wanted to present the importance of social workers in the response to the pandemic and the significance of their role in supporting vulnerable adults, children, and families, focusing, in particular, on our countries of Slovenia and England. Social workers are utilizing ICT technologies to develop virtual social contact and support as contact in the physical space is limited. However, we have witnessed self-organised volunteering based on mutual aid principles and the development of solidarity among communities in our respective countries.

In Slovenia, care for older and disabled people is dominated by a rigid system of institutions, which do not meet the needs of the heterogeneous group of older people [4], and the lack of community-based care is one of the persistent problems obstructing the development of care for older people; we therefore believe that the pandemic presents an opportunity to innovate towards more user-centred practice. In England, social work may have the potential to develop a stronger presence in the community. We believe that social workers respond in creative ways to all those changes during the pandemic and that social care practitioners in our local and international contexts have the knowledge and skills to drive service improvement.

In the future, we are hesitant about the potential for change; we fear that disappointingly 'innovation without change' [6] may reign as we reconfigure health and social care services in response to Covid-19. The slowdown in the international economies has led to shrinking international funds and national Gross Domestic Product (GDP). This will impact inevitably on the resources available for the development and delivery of future health and social care services, and the amount of support offered to social workers. Although the development of CSW and community mobilisation suggest the potential for change, it may be that the opportunities for innovation are lost due to financial expediency and the sense of hope and optimism for the potential for change following this terrible pandemic will be dashed. Moreover, if a second wave of the pandemic were to occur, social workers would need to reassess their response and early moves to re-establish contact in the physical space, would need to be retrenched as virtual connections are re-instituted and face-to-face contacts restricted [35-51].

\section{Declaration of Interest}

The research was not supported by any grant awards.

The authors report no declaration of interest.

\section{References}

1. (2021) World Health Organisation: Slovenia.

2. Reluga T (2010) Game theory of social distancing in response to an epidemic. PLOS Computational Biolog 6 (5): e1000793.

3. Flaker V (1998) Odpiranje norosti, Vzpon in padec totalnih ustanov (Opening Madness: The rise and fall of total institutions. Ljubljana: University of Ljubljana. 
4. Mali J (2012) Uvajanje dezinstitucionalizacije na področju oskrbe starih ljudi. Časopis za kritiko znanosti (Introducing the Deinstitutionalization to the Care for Elderly people) 39(250): 86-94.

5. Braye S, Preston Shoot M (2019) The Care Act 2014: Wellbeing in practice (Transforming Social Work Practice Series). England.

6. Brandon D (1991) Innovation without change: Consumer power in psychiatric services. England.

7. (2020) c BASW Ethical guidance for social workers.

8. Leskošek V and Mešl N (2020) Slovenia. In: Dominelli L, et al. (Eds.). Covid-19 and social work: a collection of country reports. IASSW, p.100109.

9. Romanou E and Belton E (2020) Isolated and struggling: Social isolation and the risk of child maltreatment, in lockdown and beyond. NSPCC Learing.

10. (2020) Trussell Trust.

11. (2020) a BASW Professional practice guidance for hospital social workers for adults during Covid-19.

12. (2020) b BASW Professional practice guidance for home visits during Covid-19.

13. Egan G, Schroeder W (2009) The skilled helper. New York: Nelson Education.

14. Banks S, Cai T, de Jonge E, Shears J, Shum M, A, et al. (2020) Ethica challenges for social workers during Covid-19: A global perspective. Rheinfelden, Switzerland: International Federation of Social Workers.

15. BASW (2020) d Digital capabilities: Ethical considerations.

16. Videmšek P (2012) Prehodnost stanovanjskih skupin- kje se izgublja proces dezinstitucionalizacije? (Are group homes still intermediary: witnessing a twist of Deinstitutionalisation). Časopis za kritiko znanost 39(250): 74-85.

17. Videmšek P (2020) Eutopia's ambitions in the field of inclusion. Digital inclusion conference.

18. Flaker V, Mali J, Urek M (2008) Deinstitutionalization process in longterm mental health institutions in Slovenia. Conference monograph: Vilnius Lithuania, Europe.

19. Osredkar R (2020) Zakaj tako s starejšimi. [Why is it like this for the elderly?]. Mladina.

20. Oven A (2020) The impact of COVID-19 on people who use and provide long-term care in Slovenia and mitigation measures.

21. Flaker V and Ramon S (2020) Social work and deinstitutionalization.

22. Pantazis C (2016) Policies and discourses of poverty during a time of recession and austerity. Critical Social Policy 36(1): 13-33.

23. Levitas R (2012) The Just's umbrella: austerity and the Big Society in Coalition policy and beyond. Critical Social Policy 32(3): 320-342.

24. Butler P (2015) Health, housing, poverty: the coalition's social policy record audited.

25. Cunningham J, Cunningham S (2016) Sociology and social work. Exeter: Learning Matters Ltd.

26. Whittington C (2016) The promised liberation of adult social work under England's 2014 Care Act: Genuine prospect or false prospectus? Br J of Soc Work 46: 1942-1961.

27. Children Act (2004) London: HMSO.
28. BBC (2012) Timeline: Winterbourne View Abuse Scandal.

29. Bound Alberti F (2020) Coronavirus is revitalising the concept of community for the $21^{\text {st }}$ century.

30. Walker C (2020) What is remarkable about what we've achieved is that it's unremarkable. The Psychologist 33: 50 -53.

31. Mantle G, Backwith D (2010) Poverty and social work. The British Journal of Social Work 40(8): 2380-2397.

32. International Federation of Social Workers (IFSW) (2014) Global definition of Social work.

33. Bronfenbrenner U (1979) The ecology of human development. Harvard: Harvard University Press.

34. Backwith D (2015) Social work, poverty, and social exclusion Maidenhead: Open University Press, UK.

35. (2020) Act of Long-Term Care. Slovenia.

36. (2020) Association of Centres of Social Work. Instructions for users on accessibility of social services.

37. S, Cai T, de Jonge E, Shears J, Shum M, et al. (2020) Ethical challenges for social workers during Covid-19: A global perspective. Rheinfelden, Switzerland: International Federation of Social Workers.

38. (1982) The Barclay Report Social workers: Their role and tasks. London: HMSO.

39. Government of the Republic of Slovenia 2020b. Measures to mitigate the consequences of the epidemic.

40. Government of the Republic of Slovenia. 2020c. Navodila za ustrezno zaščito vseh.

41. Uporabnikov in zaposlenih na področju socialnega varstva (Instructions for protection of users and employees in social protection sector).

42. Government UK (2021) Gov. UK Coronavirus (Covid-19) in the UK.

43. Hrovatič (2020) Socialno delo v izrednih razmerah (Social work in crisis circumstances). Slovenia.

44. Hrovatič D (2020) Socialni delavci opozarjajo na naujno prenovo sistema socialnega varstva.

45. National Institute of Public Health (2020) Statistics on coronavirus SARS Co-V2 (COVID-19).

46. Novak M (1997) Razvoj evropskih modelov države blaginje (Development of European models of the welfare state). Ljubljana. VŠSD, Inštitut republike Slovenije za social varstvo.

47. (2017) Zakon o dolgotrajni oskrbi in obveznem zavarovanju za dolgotrajno oskrbo.

48. Plesničar M, Drobnjak M, Filipčič K (2020) Kriminaliteta v času COVID-19 (Criminality in times of COVID-19).

49. Rajšek B, Javornik Š (2020) Za boleznijo COVID-19 umirajo predvsem v domovih zastarejše' ('The most deaths due to COVID-19 disease are in residential homes for older people').

50. Rapoša Tajnšek P (1993) Skupnostno socialno delo in skupnostna usmeritev $\mathrm{v}$ praksi socialnega dela (Community social work and community oriented social work in the practice of social work in Slovenia). Soc delo 32(5-6): 139-151.

51. Stepney P and Popple K (2008) Social work and the community: A critical context for practice. Basingstoke: Palgrave Macmillan. Slovenia News. 